\title{
IMPLIKASI TEOLOGIS TENTANG HUKUM ROH YANG MEMERDEKAKAN DARI HUKUM DOSA DAN HUKUM MAUT DALAM ROMA 8:2
}

\author{
Agustin Soewitomo Putri \\ (STT Torsina Surakarta: tasoewitomoputri@gmail.com)
}

\begin{abstract}
Mankind has fallen into sin and lost the glory of God. The fall of man into sin made man have a tendency to sin. This is what is called the law of sin and death. The law of death follows the law of sin. The two laws are closely related. Humans need the antithesis of the law of sin and death. Romans 1-8 leads people to the law of the Spirit. The law of the Spirit is great news in the midst of mankind's struggle

to experience victory over sin and death.
\end{abstract}

Key Word: law, sin, death, Spirit.

\section{A. PENDAHULUAN}

Kematian Kristus di atas kayu salib adalah puncak dari terselenggaranya rencana Allah dalam misi keselamatan umat manusia. Firman Allah menyatakan bahwa tidak ada penghukuman bagi mereka yang ada di dalam Kristus Yesus, kuasa dosa telah ditaklukkan dibawah kakiNya. Paulus berkata, "Pada saat kamu menyerahkan dirimu kepada dosa dan menjadi hambanya; kebenaran tidak berkuasa apa-apa atasmu. Tetapi sekarang kamu telah menyerahkan dirimu kepada Allah dan menjadi hamba kebenaran, dengan demikian dosa tidak berkuasa apa-apa atasmu". ${ }^{1}$ Pokok gagasan pembenaran ialah penyataan Allah, hakim yang adil, bahwa orang yang percaya kepada Kristus, sekalipun penuh dengan dosa, dinyatakan benar - dipandang sebagai benar, karena di dalam Kristus orang tersebut telah memasuki suatu hubungan yang benar dengan Allah". ${ }^{2}$ Keselamatan yang diterima manusia adalah anugerah dan manusia berdosa dimampukan menerimanya hanya karena tindakan pembenaran yang dilakukan oleh Allah Bapa.

Perubahan status manusia dari musuh menjadi sekutu Allah tidak berarti bahwa pembenaran yang sudah dikerjakan Allah melalui kematian Kristus di atas kayu salib menjadi sebuah kenyataan yang final. Dalam dokumen JDDJ ${ }^{3}$ ditekankan dua hal sehubungan dengan perubahan status manusia. Bagian yang pertama adalah justification (pembenaran) yang dilihat sebagai karya dari Allah kepada manusia yang berdosa dan bagian kedua adalah sanctification (pengudusan) yang dipahami sebagai kesempatan manusia bergerak mendekati Allah, "to be with God as a faithful covenant partner"

${ }^{1}$ William Barclay, Pemahaman Alkitab Setiap Hari - Surat Roma (Jakarta: BPK Gunung Mulia, 2007), 136

${ }^{2}$ George Eldon Ladd, A Theology of the New Testament (Grand Rapids: Wm. B. Eerdmans Publishing Co., 1974), 437.

${ }^{3}$ JDDJ (Joint Declaration of The Doctrine of Justification) adalah penandatanganan kesepakatan Gereja Roma Katolik dan Federasi Lutheran untuk menerima doktrin pembenaran oleh iman (anugerah). Penandatanganan tersebut diadakan pada tanggal 31 Oktober 2017 sekaligus untuk peringatan 500 tahun aksi penempelan 95 dalil dipintu gereja di Wittenberg oleh Luther pada tanggal 31 Oktober 1517. 
(bersama Allah sebagai rekan perjanjian yang setia). Justification (pembenaran) bersifat selesai atau tuntas. Kristus membuat manusia yang berdosa menjadi benar sedangkan dalam sisi pengudusan (sanctification) bersifat bertumbuh. ${ }^{4}$ Ada dua sudut pandang dalam perubahan status manusia lama yang kemudian menjadi manusia baru. Pertama, dari sudut pandang Allah perubahan status tersebut sudah tuntas (bersifat perfectum). Manusia telah dibenarkan dan tidak ada lagi korban penghapus dosa (Ibr.10:26-27), artinya pembenaran tersebut berlaku dalam diri manusia untuk apa yang sudah dilakukan dan akan dilakukan. Kedua, dari sudut pandang manusia perubahan status tersebut masih dalam proses. Manusia masih dalam pergumulan menanggalkan tabiat berdosanya untuk menunjukkan citra dirinya sebagai manusia baru.

Proses pergumulan manusia dalam perubahan status tersebutlah yang menjadi medan peperangan yang tidak akan selesai hingga manusia menutup mata. Faktanya bahwa manusia yang telah dibenarkan tetap diperhadapkan dengan keinginan-keinginan berdosa, hal ini dikatakan Paulus kepada jemaat di Galatia "Sebab keinginan daging berlawanan dengan keinginan Roh dan keinginan Roh berlawanan dengan keinginan daging....karena keduanya bertentangan....sehingga kamu setiap kali tidak melakukan apa yang kamu kehendaki (Gal. 5:17) dan dalam Roma 7: 21-24, Paulus mengungkapkan ketidakberdayaan terhadap hukum Taurat yang membawanya pada pengenalan dosa dengan kalimat yang bernada keputusasaan "Demikianlah aku dapati hukum ini: jika aku menghendaki berbuat apa yang baik, yang jahat itu ada padaku. Sebab di dalam batinku aku suka akan hukum Allah, tetapi di dalam anggota-anggota tubuhku aku melihat hukum lain yang berjuang melawan hukum akal budiku dan membuat aku menjadi tawanan hukum dosa yang ada di dalam anggota-anggota tubuhku. Aku, manusia celaka! Siapakah yang akan melepaskan aku dari tubuh maut ini?", artinya bahwa dalam perubahan status tersebut ada hukum dosa yang terus mencoba melawan untuk manusia berada dalam status taat kepada kebenaran.

Dalam Kamus Besar Bahasa Indonesia ada beberapa arti hukum, yaitu:

1. Peraturan atau adat yang secara resmi dianggap mengikat, yang dikukuhkan oleh penguasa atau pemerintah;

2. Undang-undang, peraturan, dan sebagainya untuk mengatur pergaulan hidup masyarakat;

3. Patokan (kaidah, ketentuan) mengenai peristiwa (alam dan sebagainya) yang tertentu;

4. Keputusan (pertimbangan) yang ditetapkan oleh hakim (dalam pengadilan); vonis; ${ }^{5}$

Secara umum hukum seringkali dipahami sebagai sebuah aturan atau undang-undang, sedangkan pemahaman hukum sebagai sebuah kaidah atau ketentuan lebih banyak ditemukan dalam dunia sains. Sebagai sebuah gambarannya adalah Hukum Gravitasi yang ditemukan oleh Issac Newton. Newton adalah orang pertama yang mengemukakan gagasan tentang adanya gaya gravitasi. Gagasan tentang

${ }^{4}$ https://www.researchgate.net/publication/339026924_Analisis_Teologis_Konsep_Pembena ran_Berdasarkan_Pengakuan_Iman_Westminster_dan_Katekismus_Heidelberg_A_Theological_Anal ysis_of_the_Concept_of_Justification_Based_on_the_Westminster_Confession_of_Faith

5“Arti Hukum," https://kbbi.web.id/hukum. 
gaya gravitasi ini diawali dari pengamatan Newton pada peristiwa jatuhnya buah apel dari pohonnya, yang kemudian melalui penelitian lebih lanjut mengenai gerak jatuhnya benda-benda, Newton menyimpulkan bahwa apel dan setiap benda jatuh karena tarikan Bumi. Gaya tarik bumi terhadap benda-benda ini dinamakan gaya gravitasi bumi. ${ }^{6}$ Hukum ini akan berlaku di setiap tempat dan waktu

"Hukum" dalam pemahaman yang lebih sederhana adalah sesuatu yang terus-menerus berlangsung demikian, tanpa pengecualian; dan memiliki kekuatan. Kekuatan hukum adalah sesuatu yang spontan dan tidak perlu dikerjakan oleh usaha manusia. Asalkan sesuatu itu adalah hukum, ia pasti memiliki kekuatan. ${ }^{7}$ Berlakunya suatu hukum adalah otomatis. Manusia yang hidup di bumi tidak bisa tidak mengalami hukum meskipun sebuah hukum akan dapat digugurkan oleh hukum yang lain. Hukum gravitasi bumi tidak akan berlaku jika ada hukum ketiga Newton yang menggambarkan hubungan antara gaya yang bekerja pada suatu benda dan gerak yang disebabkannya ${ }^{8}$, seperti pada pesawat terbang. Manusia secara alami hidup di bawah sebuah hukum, namun demikian akan ada hukum-hukum lain yang berlaku dan kemungkinan dapat menjadi antitesisnya. Prinsip ini pun berlaku dalam Alkitab: ada hukum yang melawan hukum dosa dan hukum maut yang menguasai manusia.

Beranjak dari penggambaran kedudukan manusia yang telah dibenarkan karena penebusan Kristus dan kenyataan bahwa manusia ada dalam pergumulan kecenderungan berbuat dosa, maka Roma 8 menjadi sebuah catatan yang menarik dari Rasul Paulus tentang sebuah titik balik bagaimana hukum dosa dan hukum maut itu dapat dilawan. Ada hukum yang lain yang menjadi antitesis dari hukum tersebut dan Paulus menyebutkannya dengan hukum Roh yang hidup (Rm. 8:2). Hukum Roh yang hidup membuat manusia berdosa dibebaskan dari hukum dosa dan hukum maut. Kekuatan manusia tidak akan pernah dapat menyelesaikan persoalan pergumulan dosa ini, namun kehadiran Roh Kudus dan karyaNya melalui hukum Roh yang hidup menjadi kunci kemenangan untuk dapat mengalami kemerdekaan tersebut.

\section{Pemahaman tentang Dosa}

Dosa memiliki arti dasar: tidak mengena pada sasaran, memberontak atau melawan, melanggar batas, meleset dari tujuan, tidak taat atau tidak patuh. Dosa juga dapat didefinisikan sebagai pemberontakan secara aktif terhadap Allah sehingga menyebabkan manusia melanggar hukum Allah, hidup dalam ketidaktaatan dan menyimpang dari tujuan Allah yang menciptakannya serta hidup berkontradiksi dengan kekudusan Allah. Dyrness menyatakan bahwa kejatuhan manusia adalah asal mula dosa. Dosa yang menjadi penyebab utama terputusnya hubungan antara manusia dengan Allah.

\footnotetext{
6“Gravitasi Newton," last modified 2016, https://sumberbelajar.belajar.kemdikbud.go.id/sumberbelajar/tampil/Gravitasi-Newton-20162016/menu3.html.

${ }^{7}$ https://kebenaransaja.wordpress.com/2015/09/22/14-kelepasan/

${ }^{8}$ https://www.studiobelajar.com/hukum-newton-1-2-3/
} 
Manusia menerima kutuk, tanah pun menjadi terkutuk dan penderitaan menjadi bagian hidup dari manusia. ${ }^{9}$ Pandangan yang lain diungkapkan oleh Buswell yang berpendapat bahwa dosa bermula dalam suatu tindakan kehendak bebas dimana ciptaan secara sengaja, bertanggung jawab dan dengan pokok pengertian yang memadai tentang pokok persoalan itu memilih untuk merusak sifat keilahian yang kudus yang telah Allah berikan kepada ciptaanNya. ${ }^{10}$

Urban menjelaskan tentang dosa ditinjau dari Perjanjian Lama, bahwa konsep dosa memiliki beberapa lapisan:

Lapis pertama bermakna kecemaran dan kegagalan moral; lapis yang kedua memiliki makna kegagalan dalam melakukan kehendakNya, kegagalan memelihara perjanjianNya dan kegagalan dalam menjalin hubungan secara personal dengan Allah; lapisan yang ketiga dalam penggunaan kata dosa adalah "kesalahan". Rasa bersalah mencakup bukan hanya pengakuan akan kegagalan dalam mencapai sasaran atau pelanggaran melawan hukum Allah, melainkan juga menekankan perwakilan pribadi. Dalam hal ini, putusnya hubungan pribadi dengan Allah menjadi sesuatu yang lebih merusak sifatnya disertai dengan perwakilan atau pertanggungjawaban pribadi. Pada lapis ke empat, Perjanjian Lama berbicara tentang dosa sebagai sebuah situasi keberadaan yang menuntun atau menyebabkan tindakan dosa. ${ }^{11}$

Pusat dari ajaran Yesus dalam Injil tidak berbeda dengan konsep dalam Perjanjian Lama yang memandang dosa sebagai sebuah pencemaran, kesalahan akibat pelanggaran atas perintahperintah Allah dan penolakan terhadap kasih Allah itu sendiri. Yesus prihatin dengan berbagai kecenderungan pada kejahatan yang telah melekat dalam hati manusia (Mat. 15:19) ${ }^{12}$. Paulus dalam penjelasannya tentang dosa asali ( $\mathrm{Rm} .5$ ) konsisten dengan pandangan tradisional yang memberikan penjelasan klasik pada doktrin tersebut. Pertama, Paulus menyebutkan bahwa kematian jasmani maupun kematian jiwa adalah hukuman untuk dosa Adam. Kedua, Adam adalah orang berdosa pertama dan generasi berikutnya menjadi orang berdosa melalui dia yang dalam hal ini kecenderungan berdosa diwarisi secara biologis, namun itu tidak berarti mengakhiri berbagai kemungkinan. Suatu kecenderungan berdosa bisa dialihkan secara psikologis daripada secara genetis. Paulus juga berbicara tentang dosa sebagai semacam kekuasaan yang mengendalikan atau mempengaruhi umat manusia untuk melakukan tindakan imoral (Rm. 7:20) yang juga berarti bahwa semua orang gagal untuk melaksanakan hukum itu karena manusia di bawah kekuasaan dosa (Rm. 3:9). ${ }^{13}$

Membahas tentang dosa tidak dapat dilepaskan dari akibat dosa itu sendiri yaitu maut. Roma 8:2 menggunakan kata "maut" dengan bahasa Yunaninya adalah "thanatos". Kata "thanatos" memiliki beberapa makna yaitu: kematian dari tubuh yang memisahkan (baik yang alami atau kasar)

2013).

${ }^{9}$ William Dyrness, Tema-Tema dalam Teologi Perjanjian Lama (Malang: Gandum Mas,

${ }^{10}$ Charles C. Ryrie, Teologi Dasar 1: Panduan Populer untuk Memahami Kebenaran Alkitab (Yogyakarta: Andi Offset, 2014), 203.

${ }^{11}$ Linwood Urban, Sejarah Ringkas Pemikiran Kristen (Jakarta: BPK Gunung Mulia, 2003), 165-168.

${ }^{12}$ Linwood Urban, 171.

${ }^{13}$ Ibid., 173. 
dari jiwa dan tubuh yang melaluinya kehidupan di bumi berakhir; kesengsaraan masa depan di neraka, kekuatan maut, dunia bawah, tempat tinggal orang mati, tempat yang sangat gelap (setara dengan wilayah kegelapan paling tebal); secara kiasan disebutkan dengan wilayah yang diselimuti kegelapan, ketidaktahuan dan dosa, kesengsaraan jiwa yang timbul dari dosa yang dimulai di bumi tetapi bertahan dan bertambah setelah kematian tubuh di neraka; keadaan sengsara orang fasik yang mati di neraka. Kematian terdiri dari semua kesengsaraan yang timbul dari dosa, serta kematian jasmani sebagai hilangnya nyawa.

Kejatuhan manusia pertama dalam dosa dan keberadaan manusia sampai hari ini tidaklah dapat dilepaskan dari cengkeraman dosa itu sendiri. Salah satu dari tiga aspek dosa disebutkan dengan aspek habitus, artinya dunia yang menjadi tempat manusia dilahirkan adalah dunia yang telah berdosa. Lingkungan tempat manusia dilahirkan ada dalam kondisi berdosa. Hal ini juga memungkinkan semua manusia memiliki kecenderungan berdosa dan kecenderungan berbuat jahat. Kondisi keberdosaan juga menyebabkan manusia menularkan kebiasaan berdosa yang semuanya membawa kebobrokan. Bergaul dengan orang fasik akan menyebabkan orang menjadi fasik juga (Ams. 11:9). Seseorang yang dibesarkan dan tinggal dalam lingkungan yang jahat akan mudah untuk jatuh dalam kejahatan. Manusia ada di bawah kuasa dosa dan hukum dosa berlaku atasnya bahwa upah dosa adalah maut (Rm. 6:23).

\section{Manusia dibawah Hukum Dosa}

Dosa dan maut juga adalah sebuah hukum. Dosa yang bersifat universal tersebut telah membuat manusia tunduk kepadanya. Paulus memulai dengan orang-orang bukan Yahudi yang "sekalipun mereka mengenal Allah, mereka tidak memuliakan Dia sebagai Allah" (Rm. 1:21). Orangorang bukan Yahudi tidak memiliki Taurat dan itu sebabnya tidak dapat dituduh melanggar Hukum Taurat, namun demikian orang-orang bukan Yahudi "menjadi hukum Taurat bagi diri mereka sendiri" (Rm. 2:14). Orang-orang bukan Yahudi dapat membedakan antara benar dan salah, itulah sebabnya jika mereka berdosa maka mereka tidak dapat berdalih (Rm. 1:20). Orang berdosa bukan hanya orang non-Yahudi, orang Yahudi memiliki hukum Taurat dalam hidupnya namun faktanya Taurat tidaklah dihidupi sebagaimana yang diinginkan Tuhan. ${ }^{14}$ Tanpa ragu-ragu, Paulus menyatakan "karena semua orang telah berbuat dosa dan telah kehilangan kemuliaan Allah" (Rm. 3:23).

Paulus juga menyatakan bahwa ada kegelisahan tersendiri jika secara universal seluruh manusia berdosa, yaitu keinginan untuk berbuat baik dimiliki manusia namun yang jahatlah yang dilakukannya. Paulus menyatakan bahwa dosa bukan hanya sebuah kejahatan yang dilakukan, namun dosa adalah suatu kekuatan yang membelenggu manusia. Bahkan sekalipun seseorang hidup didalam Taurat, maka Taurat itu justru membawa kepada kematian sebab faktanya ketaatan kepada hukum tersebut telah membawa kepada kemegahan (Flp. 3:4,7) dan keangkuhan (Rm. 2:13, 23). Keangkuhan

\footnotetext{
${ }^{14}$ Leon Morris, Teologi Perjanjian Baru (Malang: Gandum Mas, 1986), 75.
} 
adalah lawan dari iman (Rm. 4:2), karena menunjukkan upaya menetapkan kebenaran manusia melalui perbuatan (Rm. 3:27) yang mengejar kemuliaan di hadapan Allah dan bersandar pada diri sendiri. Keangkuhan dan kesombongan manusia ini merupakan dosa dihadapan Allah. ${ }^{15} \mathrm{Hal}$ ini sekaligus menjadi sebuah fakta bahwa melakukan hukum Taurat yang sesungguhnya sudah dirancangkan Tuhan dengan baik, menjadi sebuah sandungan bagi manusia yang cenderung tetap berbuat dosa.

Paulus berkali-kali menyebutkan tentang manusia sebagai hamba dosa (Rm. 6:17, 20) yang terjual dibawah kuasa dosa (Rm. 7:14). Paulus menggambarkan dirinya sebagai orang yang menjadi tawanan hukum dosa (Rm. 7:23), dimana yang menjadi gambarannya adalah seorang yang ditangkap sebagai tawanan perang. ${ }^{16}$ Hukum dosa disebutkan untuk memberikan sebuah gambaran bahwa manusia tidak dapat melepaskan diri dari sebuah dosa, bahkan sekalipun ada keinginan dan pengetahuan untuk berbuat baik namun hukum dosa tersebut tidak dapat dihindari dan pasti berlaku. Manusia tidak dapat melepaskan diri karena kuasa dosa sudah menjeratnya dan manusia telah diperbudak. Bagi manusia yang berdosa segala hawa nafsu dan keinginan daging adalah penguasa tunggal dalam hidupnya, sehingga dosa pun akan beranak dosa dan itulah sebenarnya hukum dosa itu sendiri. ${ }^{17}$

Hukum maut mengikuti hukum dosa. Kedua hukum tersebut berhubungan erat. Seseorang yang terikat pada hukum dosa maka secara otomatis orang tersebut ada dalam hukum maut yang pada akhirnya tidak bisa tidak, seluruh dosa akan berakibat pada kematian. Kematian tidak hanya berbicara pada persoalan terpisahnya jiwa dan roh dengan tubuh jasmani, namun maut disini merujuk kepada kematian kekal yaitu berakhirnya hidup manusia dalam neraka. Sesungguhnya manusia tidak dapat lagi membebaskan dirinya karena sudah terikat dalam hukum dosa dan maut, dan dalam hal ini suatu hukum hanya dapat digugurkan oleh hukum yang lain. Manusia membutuhkan antitesis hukum dosa dan hukum maut tersebut.

\section{B. METODOLOGI}

Metode yang digunakan ialah metode penelitian kualitatif dengan mengumpulkan data dari berbagai literatur seperti buku-buku teologi, tafsiran dan jurnal-jurnal yang terkait. Di sisi lain, perbandingan dengan kitab-kitab lain dalam Alkitab menjadi salah satu penunjang dalam penelitian ini yang memberikan dukungan secara pasti dalam kebenaran. Tujuan dari penelitian ini adalah untuk menemukan hubungan teologis tentang hukum Roh yang memerdekakan dari hukum dosa dan dukum maut dan kemudian menemukan implikasi teologisnya. Penelitian ini juga memerlukan studi biblika yang diambil dari Roma 8:2. Teknik penelitian meliputi semua data yang telah diperoleh, dipelajari 2008), 277.

${ }^{15}$ George Eldon Ladd, Teologi Perjanjian Baru Jilid 2 (Bandung: Yayasan Kalam Hidup,

${ }^{16}$ Ibid., 74.

${ }^{17}$ William Barclay, Pemahaman Alkitab Setiap Hari - Surat Roma (Jakarta: BPK Gunung Mulia, 2007), 139. 
dan kemudian dibandingkan satu dengan yang lainnya hingga diperoleh satu kesimpulan yang menjadi jawaban tentang hukum Roh yang memerdekakan dari hukum dosa dan hukum maut serta apa implikasinya yang menjadi jawaban dari pertanyaan-pertanyaan dalam tulisan ini.

\section{PEMBAHASAN}

1. Hukum Roh sebagai Antitesis Hukum Dosa

Rasul Paulus, dalam Surat Roma secara runtut memberikan gambaran tentang siapa manusia berdosa tersebut dan bagaimana keadaannya. Pasal 1-3, Paulus memberikan gambaran tentang orangorang Yahudi dan non-Yahudi yang mana masing-masing memiliki hukum, namun hanya bermanfaat untuk menunjukkan dosa kepada manusia dan manusia tidak akan dapat diselamatkan karena ketaatannya tersebut. Pasal yang ke-4, Paulus menyebutkan tentang anugerah Tuhan yang dapat menyelamatkan manusia yang terbukti dalam diri Abraham yang hidup sebelum Taurat diberikan. Abraham dibenarkan hanya karena kasih karunia Allah (Rm. 4:13). Pasal yang ke-5, Paulus menunjukkan bahwa dosa yang bertambah besar diikuti dengan kasih karunia dari Allah yang makin melimpah-limpah. Pasal 6 dituliskan tentang manusia yang hidup dibawah kasih karunia dan sesungguhnya tidak lagi hidup dibawah hukum dosa. ${ }^{18}$

Pasal yang ke-7 seolah menjadi sebuah catatan puncak tentang keadaan manusia yang hidup dalam Taurat dan ketidakberdayaannya melawan hukum dosa. Paulus mengawali dengan memberikan penjelasan melalui sebuah analogi hidup suami-istri dalam sebuah pernikahan. Sepasang suami-istri terikat dalam hukum pernikahan dan hukum itu akan menjadi "mentah" tidak berlaku pada saat salah satu dari pasangan tersebut mati. Paulus ingin menekankan prinsip bahwa seseorang bebas dari hukum apabila terjadi kematian. ${ }^{19}$ Pasal 7 terbagi menjadi tigas garis besar: Tubuh atau manusia lama harus dibinasakan (ay. 1-6); Hukum Taurat berhubungan dengan dosa (ay. 7-13); “Aku” (manusia tubuh lama) diserang dari luar dan dari dalam (ay. 14-25). ${ }^{20}$ Teks dalam pasal 7 memberi gambaran ketidakberdayaan manusia untuk lepas dari hukum dosa dan hukum maut dan pasal 8 menjadi sebuah kebangkitan dari keterpurukan manusia karena hukum dosa. Pasal 8 dibuka dengan sebuah pernyataan "demikian sekarang tidak ada penghukuman...", frasa ini mengindikasikan tentang kesimpulan dari apa yang tertulis sebelumnya yaitu ketidakberdayaan manusia yang hidup di bawah hukum Taurat dan diikat dengan hukum dosa. Ayat 2 menjadi sebuah jawaban dari apa dan siapa yang mampu membawa manusia kepada kemerdekaan dari hukum dosa dan hukum maut tersebut.

Alkitab Terjemahan Baru menuliskan Roma 8:2 sebagai berikut: "Roh yang memberi hidup telah memerdekakan kamu dalam Kristus dari hukum dosa dan hukum maut”. Terjemahan King

\footnotetext{
${ }^{18}$ R. A. Jaffray, Tafsiran Surat Roma (Bandung: Kalam Hidup, 2007), 132.

${ }^{19}$ Brury Eko Saputro, Mengenal Surat Rasul Paulus Kepada Jemaat di Roma (Malang: DIOMA, 2019), 106.

${ }^{20}$ opcit., 132.
} 
James Version (KJV) menuliskan "For the law of the Spirit of life in Christ Jesus hath made me free

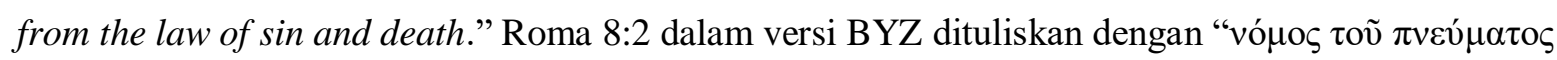

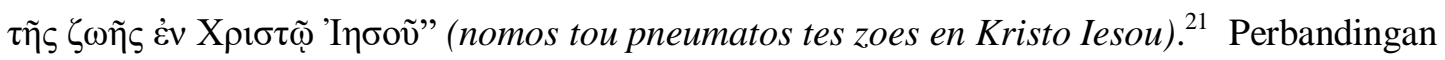
beberapa terjemahan tersebut memiliki perbedaan yang cukup berarti, seperti dalam Alkitab TB dapat dipahami secara sederhana bahwa Roh Kudus telah memerdekakan dalam Kristus dari hukum dosa dan hukum maut. Terjemahan KJV dan beberapa terjemahan lain menyebutkan bukan hanya "Roh" namun disebutkan sebagai "Hukum Roh", demikian juga dalam teks bahasa asli yang disebutkan dengan "nomos tou pneumatos tes zoes...” yang dapat diterjemahkan dengan "hukum Roh kehidupan".

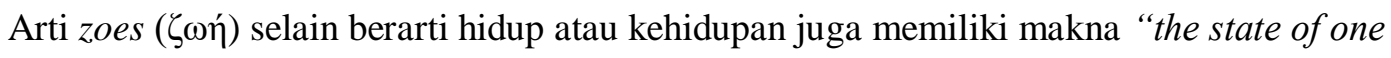
who is possessed of vitality or is animate" (keadaan seseorang yang memiliki vitalitas atau menghidupkan atau menggerakkan). Penegasan dari teks tesebut adalah hukum Roh yang memberi hidup ini adalah kuasa dan hidup yang bekerja dalam hati orang percaya yang digerakkan oleh Roh Kudus sendiri. Roh Kudus memasuki kehidupan orang berdosa dan membebaskan mereka dari kuasa dosa (Rm. 7:23). ${ }^{22}$ Hukum Roh hanya akan dimiliki oleh orang-orang yang hidup didalam Kristus, mengalami kelahiran baru dan mempunyai penundukan diri untuk hidup dalam ketaatan pada pimpinan dan karya Roh Kudus. Hukum Roh kini bekerja secara leluasa pada saat orang percaya menyerahkan diri untuk menaati Roh (ay. 4-5; 13-14). Orang-orang percaya mendapati kekuatan baru yang bekerja dalam dirinya, suatu kuasa yang memungkinkan mereka mengatasi dosa. Hukum dosa dan hukum maut adalah kuasa dosa yang mengikat sehingga memperbudak orang (Rm. 7:14) dan membawa mereka pada keadaaan yang menyedihkan (Rm. 7:24). ${ }^{23}$ Demikianlah ayat ini mengacu kepada sebuah pemahaman tentang adanya hukum Roh yang menggerakkan atau menghidupkan dan telah memerdekakan orang percaya dari hukum dosa dan hukum maut. Artinya, status orang percaya sebagai orang yang bebas dari hukuman adalah dampak dari hukum Roh di dalam Yesus Kristus. ${ }^{24}$

\section{Implikasi Hukum Roh yang Memerdekakan}

Hukum dari Roh yang hidup adalah hukum Roh Kudus itu sendiri. Hukum ini berlaku otomatis dalam hidup orang percaya pada saat dia telah menerima Kristus sebagai Juruselamat hidupnya. Hukum Roh yang memerdekakan itu akan membuat orang percaya:

a. Mampu untuk tidak hidup menurut daging (Rm. 8:4,13).

b. Memikirkan hal-hal yang dari Roh (Rm. 8:5).

c. Menjadi milik Kristus (Rm. 8:9).

\footnotetext{
${ }^{21}$ https://alkitab.sabda.org/bible.php?book=Rom\&chapter $=8$

${ }^{22}$ Stanley M.Horton, et.all., Alkitab Penuntun Hidup Berkelimpahan (Malang: Gandum Mas, 1994)., 1853.

${ }^{23}$ Ibid., 1853.

${ }^{24}$ Brury Eko Saputro, opcit. 115.
} 
d. Roh manusia dihidupkan (Rm. 8:10).

e. Mendapat status anak Allah (Rm. 8:14-16).

f. Berhak menerima janji-janji Allah (Rm. 8:17).

g. Dimerdekakan dari perbudakan kebinasaan dan terhisap dalam kemerdekaan kemuliaan anak-anak Allah (Rm. 8:21).

h. Menerima kekuatan untuk bertahan dalam penderitaan (Rm. 8:20-25).

i. Menerima pertolongan dalam kelemahan melalui Roh yang berdoa kepada Allah (Rm. 8:26, 27).

j. Ditentukan menjadi serupa dengan gambaran Kristus, dibenarkan dan dimuliakan (Rm. 8:29, 30).

k. Mendapatkan segala karunia bersama-sama dengan Kristus (Rm. 8:32).

\section{KESIMPULAN}

Serangkaian Surat Roma pasal 1 hingga 8 dapat disimpulkan bahwa hukum Roh adalah sebuah berita besar di tengah pergumulan manusia untuk mengalami kemenangan terhadap dosa dan maut. Pembenaran (justification) yang sudah dikerjakan Allah yang sempurna telah selesai, dan manusia diperhadapkan dengan sebuah pergumulan untuk tetap ada dalam keselamatan dan disucikan. Keadaan manusia yang ada dalam hukum dosa menjadi tantangan yang berat untuk bertahan dalam kebenaran dan melakukan Firman Tuhan seperti yang seharusnya dirindukan Tuhan. Setiap orang yang hidup dalam Kristus mengalami penebusan darah Anak Domba yang secara otomatis tidak lagi ada di bawah hukum dosa akan tetapi hidup dalam hukum Roh. Hidup dalam hukum Roh bukan berarti imun dari dosa. Tantangan berikutnya adalah bagaimana manusia yang hidup dalam hukum Roh itu mempertahankan dirinya dengan pertolongan Roh Kudus dan melakukan semua aturan atau dalam pemahaman sederhanaya adalah bagaimana manusia hidup dalam Firman Tuhan itu sendiri. Hukum dosa dan maut telah dipatahkan dengan perpindahan posisi tersebut dan secara otomatis setiap umat percaya hidup dalam kemerdekaan. 


\section{DAFTAR PUSTAKA}

Gidion, Gidion. "Kecakapan Lulusan Pendidikan Tinggi Teologi Menghadapi Kebutuhan Pelayanan Gereja dan Dunia Pendidikan Kristen." KURIOS (Jurnal Teologi dan Pendidikan Agama Kristen) 6.1 (2020): 73-86.

Ladd, George Eldon. A Theology Of The New Testament. Grand Rapids: Wm B. Eerdmands Publishing Co., 1974.

—. Teologi Perjanjian Baru Jilid 2. Bandung: Yayasan Kalam Hidup, 2008.

Leon Morris. Teologi Perjanjian Baru. Malang: Gandum Mas, 1986.

Manogu, Fergindo Reza Kaligis and Ridwanta. "Analisis Teologis Konsep Pembenaran Berdasarkan Pengakuan Iman Westminster Dan Katekismus Heidelber." Diligentia: Journal of Theology and Christian Education 2 No: 1 (2020): 102.

https://www.researchgate.net/publication/339026924_Analisis_Teologis_Konsep_Pembenaran_

Berdasarkan_Pengakuan_Iman_Westminster_dan_Katekismus_Heidelberg_A_Theological_Anal ysis_of_the_Concept_of_Justification_Based_on_the_Westminster_Confession_of_Faith.

R.A. Jaffray. Tafsiran Surat Roma. Bandung: Kalam Hidup, 2007.

Ryrie, Charles C. Teologi Dasar 1: Panduan Populer Untuk Memahami Kebenaran Alkitab. Jakarta: BPK Gunung Mulia, 2014.

Saputro, Brury Eko. Mengenal Surat Rasul Paulus Kepada Jemaat Di Roma. Malang: DIOMA, 2019. Stanley M.Horton, et.all. Alkitab Penuntun Hidup Berkelimpahan. Malang: Gandum Mas, 1994. Urban, Linwood. Sejarah Ringkas Pemikiran Kristen. Jakarta: BPK Gunung Mulia, 2003.

William Barclay. Pemahaman Alkitab Setiap Hari - Surat Roma. Jakarta: BPK Gunung Mulia, 2007.

William Dyrness. Tema-Tema Dalam Teologia Perjanjian Lama. Malang: Gandum Mas, 2013.

“Arti Hukum.” https://kbbi.web.id/hukum.

"Arti Kematian.” https://alkitab.sabda.org/expository.php?word=kematian.

“Gravitasi Newton.” Last modified 2016.

https://sumberbelajar.belajar.kemdikbud.go.id/sumberbelajar/tampil/Gravitasi-Newton-20162016/menu3.html.

"Hukum Newton." https://www.studiobelajar.com/hukum-newton-1-2-3/.

“Tafsiran Surat Roma Pasal 8." https://alkitab.sabda.org/bible.php?book=Rom\&chapter=8. 